\title{
TURSKA U EUROPSKOM KONTEKSTU VANJSKOTRGOVINSKOG POSLOVANJA
}

\author{
Tihana Sudarić ${ }^{4}$, Lucija Bencarić ${ }^{5}$ \& Ružica Lončarić ${ }^{6}$
}

UDC / UDK: 339.5(560:4-67EU)

JEL classification / JEL klasifikacija: P45

DOI: https://doi.org/10.22598/pi-be/2020.14.1.173

Scientific review / Pregledni znanstveni rad

Received / Primljeno: April 17, 2020 / 17. travnja 2020.

Accepted for publishing / Prihvaćeno za tisak: May 20, 2020 / 20. svibnja 2020 .

\section{Sažetak}

Vanjska trgovima ima veliki značaj u gospodarstvu svake zemlje kroz multiplikativni efekt koji se ogleda ne samo kroz ekonomske komponente već i kroz sociokulturni razvoj. Cilj rada bio je identificirati Tursku u europskom kontekstu međunarodnih odnosa, odnosno ukazati na komparativnu i konkurentsku ulogu Turske u vanjskotrgovinskom poslovanju. Čimbenici odnosa Turske u europskom kontekstu su: demografski aspekti, sociološke i kulturološke razlike, pristupni kriteriji, ekonomski aspekti i politički izazovi. U posljednja dva desetljeća carinska unija Europske unije (EU) i Turske bila je okosnica razvoja u okviru bilateralne trgovine. U tom razdoblju Turska je postala petim glavnim trgovinskim partnerom s EU na globalnoj razini $s$ vrijednošću bilateralne trgovine od 140 milijardi eura (2017). Slično tome, EU je najvažniji trgovinski partner Turske, koja predstavlja 41\% turske globalne trgovine. Istraživanje u radu temeljeno je na analizi sekundarnih izvora podataka, a metode sinteze $i$ deskripcije primijenjene su u interpretaciji dobivenih rezultata i formiranja zaključaka. Rezultati istraživanja pokazuju kako je integracija Turske u Europsku uniju određena kako „tvrdim" ekonomskim čimbenicima korisnosti, tako i „,mekanim“

\footnotetext{
${ }^{4}$ Izv. Prof. dr. sc. Tihana Sudarić, Sveučilište Josipa Jurja Strossmayera u Osijeku, Fakultet agrobiotehničkih znanosti Osijek, Zavod za bioekonomiju i ruralni razvoj, E-mail: tihana.sudaric@fazos.hr

${ }^{5}$ Lucija Bencarić mag. ing. agr., Sveučilište Josipa Jurja Strossmayera u Osijeku, Fakultet agrobiotehničkih znanosti Osijek, Studentica diplomskog sveučilišnog studija Agroekonomika, Email: lucija.bencaric95@gmail.com

${ }^{6}$ Prof. dr. sc. Ružica Lončarić, Sveučilište Josipa Jurja Strossmayera u Osijeku, Fakultet agrobiotehničkih znanosti Osijek, Zavod za bioekonomiju i ruralni razvoj, E-mail: ruzica.loncaric@fazos.hr
} 
čimbenicima kao što su osjećaj identiteta, religije ili stavovima prema imigrantima. Iako Turska pokazuje pozitivne ekonomske trendove u europskom kontekstu, ,mekani“. čimbenici ipak predstavljaju osnovnu barijeru integracije.

Ključne riječi: vanjska trgovina, izvoz, uvoz, kulturološke razlike, Turska, Europska unija.

\section{UVOD}

Današnje svjetsko tržište je totalno, heterogeno, imperfektno, višestrukturalno i nedovoljno organizirano (Baban i Marijanović, 1998). Međunarodni monetarni fond (MMF) definira Tursku kao tržišno gospodarstvo u nastajanju. Ova zemlja ima izrazito dinamično tržište, opremljeno mrežom razvijene infrastrukture kao i konkurentnu radnu snagu. Geografska pozicija Turske kao i njezina blizina energetskim regijama Kaspijskog jezera i Središnje Azije dodatno povećavaju njezin potencijal u trgovinskom poslovanju s drugim zemljama. Od 2018. godine, Turska prolazi kroz valutnu i dužničku krizu, koju karakterizira turska lira (TRY), visoka inflacija, rastući troškovi zaduživanja i rastuće neispunjavanje obveza. Unatoč stalnom porastu izvoza, koji ima relativno nisku dodanu vrijednost, Turska ima rastući trgovinski deficit potaknut ovisnošću o uvozu energije. Automobilska i tekstilna industrija predvode tursku vanjsku trgovinu, a slijede je industrija zlata, nakita, hrane, čelika i opreme, kao i strojevi. Glavni uvozni proizvodi su vozila, ugljikovodici, lijekovi i kemijski proizvodi. Europska unija je daleko najveća turska izvozna destinacija, a slijede je Sjedinjene Države, Kina, Rusija i Irak (www.fao.org). Europska unija i Turska povezani su sporazumom o carinskoj uniji, koji je stupio na snagu 1995. godine. Turska je zemlja kandidat za pristupanje EU od 1999. godine i članica je Euro-mediteranskog partnerstva (Euromed) koje promiče ekonomske integracije i demokratske reforme. Euromediteransko partnerstvo je ključna komponenta u ostvarivanju veće ekonomske integracije u mediteranskoj regiji. Primarni razlozi za zahtjeve Turske za priključenjem Europskoj uniji su važnost trgovine ali i visoki udio Turske populacije u europskim zemljama.

\section{MATERIJALI I METODE}

Cilj rada je dati projekcije turskog poslovanja u europskom kontekstu kroz kvalitativne i kvantitativne indikatore. Kvalitativnom analizom znanstvenih radova $\mathrm{i}$ relevantih publikacija izdvojeni su ključni događaji u Turskoj kroz više od pola stoljeća koji su imali utjecaj na sadašnju gospodarsku situaciju u Turskoj. Metodama analize i sinteze navedene su projekcije znanstvene zajednice, a kroz raspravu je utvrđeno kako se autori bave analizama ključnih „tvrdih“ i „mekih“ čimbenika korisnosti u vanjskotgovinskim odnosima Turske i Europke unije. $\mathrm{Na}$ osnovu induktivnih i deduktivnih analiza utvrđeno je kako je promjenjen cilj i smjer ekonomske politike Turske koja se udaljava od pristupanja Europskoj uniji, gdje više nisu krucijalne barijere 
prekomjernih zahtjeva o nužnosti prilagodbe zakonodavstva već dugotrajna neizvjesnost koja obilježava cjelokupni proces.

Sumarno, znanstveni doprinos rada zasnovan je na prikazu velikog broja čimbenika koji utječu na pristupanje Turske EU te njihove interakcije, kao i recentne informacije o aktualnom položaju Turske na koju u velikoj mjeri utječu geopolitička situacija, migrantska kriza, promjene u unutrašnjoj i demografskoj politici te općenito zaokret u političkoj atmosferi naspram EU.

\section{MAKROEKONOMSKA OBILJEŽJA TURSKE}

Stupanj razvoja proizvodnih snaga zemlje osobito je važan čimbenik koji utječe na njen položaj u međunarodnoj trgovini (Andrijanić, 2001). Turska se često naziva "kolijevkom civilizacije", budući da je dom bogat mnoštvom plemena i naroda od najmanje 10.000 godina prije Krista. Obuhvaća Malu Aziju i dijelove Armenije, Kurdistana i Tracije. Raznolika klima u Turskoj odnosi se na suhu polu-kontinentalnu mediteransku klimu pod snažnim utjecajem mora na sjeveru, jugu i zapadu te planinama koje pokrivaju veći dio zemlje. More i planine stvaraju kontrast između unutrašnjosti i obalnog ruba. Nekoliko područja ima zimski maksimum tipičan za mediteranski režim, a ljetna suša je raširena. Međutim, nadmorska visina zemlje osigurava da su zime često hladnije nego što je to uobičajeno u mediteranskoj klimi, a postoje značajni kontrasti između zimskih i ljetnih temperatura.

Prema zadnjem popisu stanovništva (2017) Turska ima 80.810 .525 stanovnika. Turaka ima oko $70 \%, 25 \%$ su Kurdi, a 5\% ostali. Tursku populaciju čini 50,2 \% muškaraca i 49,8 \% žena. U najmnogoljudnijoj turskoj provinciji Istanbulu živi 18,6\% turske populacije, odnosno 15.029.231 stanovnika. U glavnom gradu Ankari koja je i druga najmnogoljudnija provincija živi 5.445.026 stanovnika. U Izmiru živi 4.279.677 stanovnika. Više od devet desetina stanovništva je muslimansko. Osim muslimanske većine, postoje i male populacije židova i kršćana. Kršćanski sljedbenici podijeljeni su između grčkih pravoslavaca, armenskih pravoslavnih, rimokatoličkih, protestantskih i drugih denominacija. Udjel urbanog i ruralnog stanovništva je $74 \%$ vs $26 \%$.

Od svog osnivanja 1923. godine, Turska je vodila mješovitu ekonomiju u kojoj i državna i privatna poduzeća pridonose gospodarskom razvoju (Bencarić, 2019). Gospodarstvo se transformiralo iz pretežno poljoprivredne u onu u kojoj su industrija i usluge najproduktivniji i brzo rastući sektor. Sektor usluga zapošljava 50\% radne snage, dok poljoprivreda i industrija zauzimaju otprilike jednu četvrtinu. Osim Irana, Turska je jedina bliskoistočna zemlja sa značajnim nalazištima ugljena, uglavnom na području Zonguldaka. Proizvodnja lignita je značajna. Postoji proizvodnja nafte u malom opsegu na jugoistoku zemlje, kao i u području sjeverozapadne Trakije. Ipak, to osigurava samo mali dio potreba zemlje, pa je Turska ovisna o uvoznim naftnim proizvodima. U proizvodnji električne energije koriste se lignit i nafta, a hidroenergetski resursi su u intenzivnom razvoju.

Prema zadnjim podacima turski BDP iznosi 784 milijarde \$ čime je ostvaren ekonomski rast od 2,6\% što je prikazano na slici 1. BDP p/c iznosi 10.540,62 \$. 
Slika 1. Rast BDP-a Turske od 1965. do 2016. godine

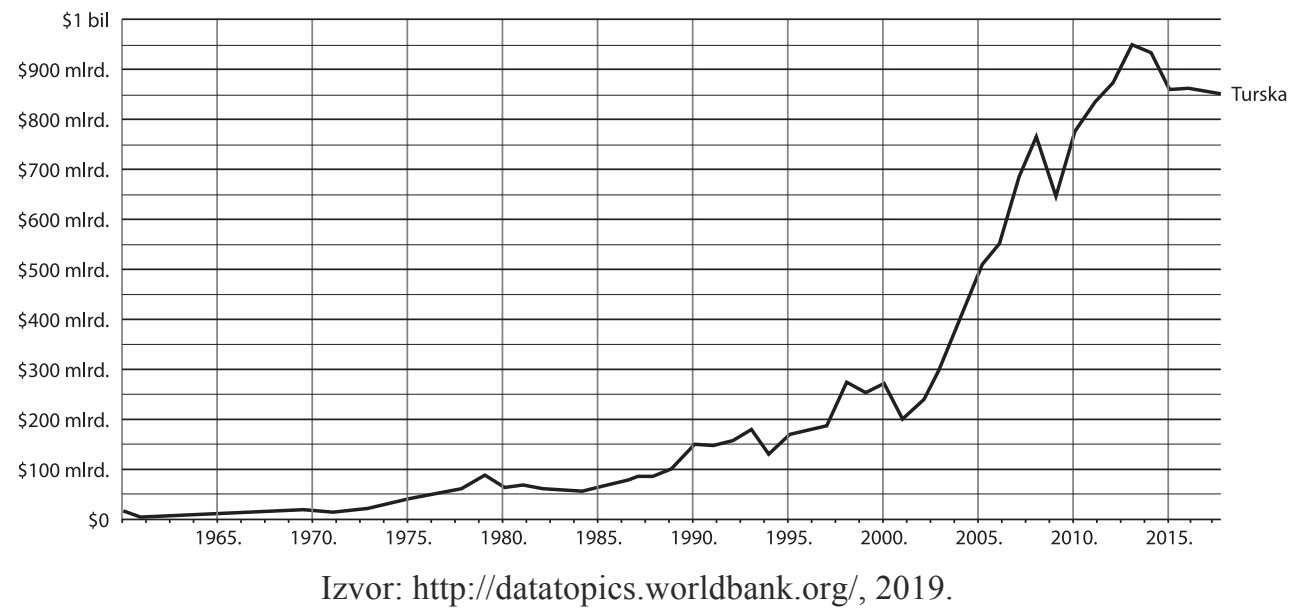

Od drugog svjetskog rata vanjska trgovina ima sve veću ulogu u turskom gospodarstvu. Do 1960. godine većina izvoza potjecala je iz poljoprivrede, a uvoz je uglavnom bio ograničen na strojeve, transportnu opremu i industrijsku robu. Razvoj proizvodnog sektora pružio je novi izvor izvoza. Vodeći izvoz su tekstilna vlakna, pređa, tkanine i odjeća, željezo i čelik, voće i povrće, stočni proizvodi, duhan i strojevi. Uvoz uključuje strojeve, kemikalije, naftne derivate, transportnu opremu i robu široke potrošnje. Otprilike polovica turske trgovine odnosi se na Europu, gdje je Njemačka glavni trgovinski partner. Rusija i Kina su glavni izvori uvoza, a značajna trgovina također se odvija na Bliskom istoku, posebno s Ujedinjenim Arapskim Emiratima i Irakom. Alžir i Izrael također su trgovinski partneri u regiji. Prema autorima Abuselidze i Mamaladze, (2019) Turska ima sve značajniju regionalnu ulogu i utjecaj. Sektori s najvišim uvoznim zahtjevima su oni s većim kapitalom i tehnološkim intenzitetom, kao što su koks i rafinirani naftni proizvodi, osnovni metali i motorna vozila. Poljoprivreda, šumarstvo i ribarstvo, usluge i rudarski sektor imaju najniže zahtjeve za uvozom (Erduman et al., 2019).

\section{VANJSKOTRGOVINSKA POLITIKA TURSKE}

\subsection{Izvoz}

Turska je 2018. godine proizvela robe i usluge u vrijednosti od 168 milijardi \$, što je za 6,6\% više od 2014. (138 milijardi \$) i 7\% od 2017. do 2018. godine (https://fao.org). Izvoz roba i usluga u Tursku čini 24,9\% ukupnog BDP-a zemlje. Iz kontinentalne perspektive, $57 \%$ turskog izvoza po vrijednosti isporučuje se europskim zemljama, dok se $25 \%$ prodaje u Aziju. Turska isporučuje 9\% robe u Afriku i 7\% za 
sjevernoameričke kupce (Graf 1). Mnogo manji postotak turskog izvoza orijentiran je na Latinsku Ameriku (2\%), isključujući Meksiko, ali uključujući Karibe.

Graf 1. Izvoz Turske po kontinentima

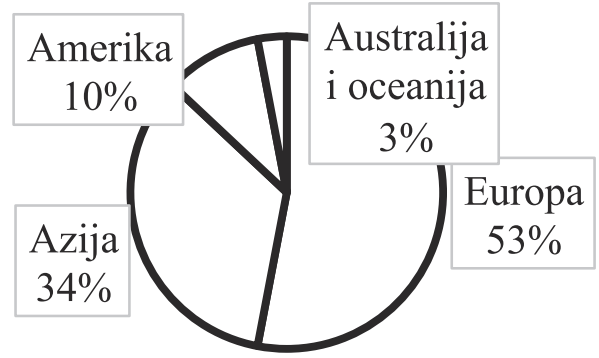

Izvor: http://worldstopexports.com/, 2019.

Tursko poljoprivredno gospodarstvo je među prvih deset na svijetu jer je ova zemlja bogata poljoprivrednim zemljištem te ima značajan udio zaposlenih $u$ poljoprivrednoj proizvodnji, ali i preradi, odnosno dodanoj vrijednosti, poljoprivredno prehrambenih proizvoda (25\%). Turska je lider u proizvodnji pšenice, šećerne repe, mlijeka, peradi, pamuka, rajčica i drugog voća i povrća, te je najveći proizvođač u svijetu marelica i lješnjaka. Dok je Turska tradicionalno bila značajan dobavljač voća i povrća, u posljednjih nekoliko godina izvoz je diversificiran kako bi uključio široku paletu proizvoda. Neki od ključnih proizvoda koji su ostvarili snažan rast su suncokretovo ulje, orašasti plodovi, grožđice, perad i brašno. Turska većinu svježeg voća i povrća izvozi u Rusku Federaciju. To tržište čini $17 \%$ tržišnog udjela ukupnog izvoza voća i povrća u Turskoj s 331 milijuna \$. Irak je drugo važno tržište s $15 \%$ tržišnog udjela s 293 milijuna \$. Njemačka je treće važno tržište u koje Turska izvozi svježeg voća i povrća u vrijednosti od 201 milijun $\$$ s tržišnim udjelom od $10 \%$ (https://fas.usda.gov). Prema ovim značajnim pokazateljima možemo govoriti o ekonomiji opsega (Matić, 2004.). Naime doprinos teoriji ekonomije opsega je u tome što dokazuju da će se isplatiti međusobno trgovati zemljama koje raspolažu sličnim proizvodnim resursima i koji proizvode s istom produktivnošću, ali pod uvjetom da jedna od njih ima prednost ekonomije opsega, jer će zbog toga proizvoditi po nižoj cijeni. Potražnja za ekološkim proizvodima također je stvorila nove izvozne mogućnosti za Tursku. Turska izvozi 1.781 vrstu poljoprivrednih proizvoda u 190 zemalja, gdje ostvaruje prihod od 16.8 milijardi \$. Mliječni proizvodi, poput jogurta, kefira, mlijeka i sira uključeni su u svakodnevni jelovnik tradicionalnih Turaka. Artisan je vrsta sira koja dominira mliječnim tržištem Turske, stoga investitori vide veliki potencijal u njegovu širenju na ostala tržišta. Turska je među prvih deset proizvođača i potrošača pšenice u svijetu. Kako je stanovništvo $99 \%$ muslimanske vjeroispovijesti, to uvelike utječe i na poljoprivredu. Turci su potpuno orijentirani na biljna ulja, najviše na suncokretovo. 
Turska proizvede pola milijuna tona leće godišnje, najvažnije leguminoze. Od industrijskog bilja značajne su količine šećerne repe, duhana i pamuka. Prirodni uvjeti pogoduju razvoju i stočarske proizvodnje (Bencarić, 2019.).

\subsection{Uvoz}

Turska je uvezla robu u vrijednosti od 223 milijarde $\$$ u 2018. godine, što je smanjenje od 7,9\% u odnosu na 2014. (242 milijarde \$). Glavne uvozne zemlje bile su Kina, Njemačka, Rusija, SAD i Italija (Graf 2.). Uvoz iz Rusije čini 13\% od ukupnog uvoza. Udio Turske u vanjskoj trgovini Rusije također je dostigao značajnu razinu. U 2017. godine Turska je, s udjelom od oko 5\%, četvrta ruska zemlja izvoza. Kina je treći trgovinski partner Turske na globalnoj razini i prvi trgovinski partner u istočnoj Aziji. Kina je 16. izvozni partner Turske i drugi uvozni partner nakon Ruske Federacije (2018.). Turska je trenutno 32. najveći trgovinski partner s SAD-om s 19,2 milijardi \$ ukupne (dvosmjerne) robne trgovine (2017.). Izvoz robe iznosio je 9,7 milijardi \$ dok je uvoz robe iznosio je 9,4 milijarde \$ (https://tradingeconomics.com). Višak trgovinske razmjene SAD-a s Turskom u 2017. godini iznosio je 328 milijuna \$. Glavne kategorije uvoza u Tursku iz SAD-a su zrakoplovi, čelik, željezo, mineralno gorivo i pamuk.

Graf 2. Uvoz u Tursku po kontinentima

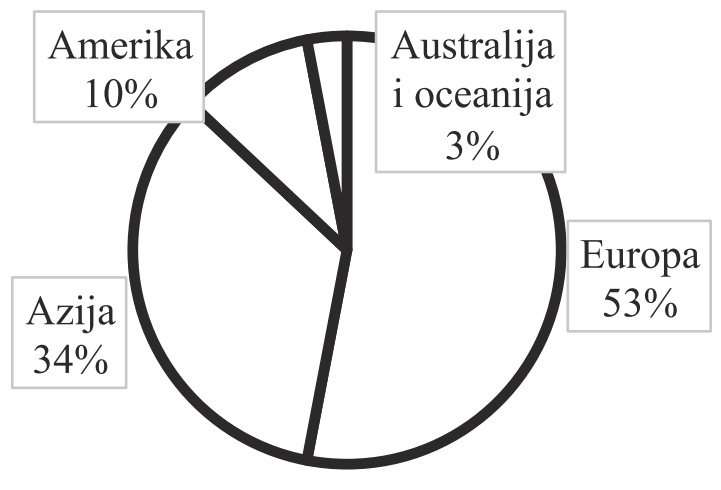

Izvor: https://tradingeconomics.com/2019.

Turska uvozi gotovo sve poljoprivredne proizvode. Primjerice, pšenica i kukuruz uvozi se iz Rusije, riža iz Rusije i SAD-a, mahunarke poput graha i slanutka iz Indije, Meksika i Kanade, te meso iz Poljske, Francuske i Bosne i Hercegovine. U 2017. godini Turska je uvezla 224 tone mesa. Iz Iraka je bilo oko $90 \%$, a oko $9 \%$ bilo je iz Mađarske. Dok je Turska ostvarila svojih 50\% izvoza ribe u Nizozemsku 2017., uvozila je ribu poput skuše, lososa, tune i sardina (Bencarić, 2019.). 


\subsection{Turska kroz međunarodne organizacije i integracije}

Turska je članica Svjetske trgovinske organizacije (WTO), Crnomorske gospodarske suradnje (BSEC), Organizacije za gospodarsku suradnju (ECO) i Inicijative za suradnju u južnoj Europi (SECI), koja potiče trgovinu sa svim svojim zemljama članicama zahvaljujući povlaštenim tarifama.

\section{Organizacija za ekonomsku suradnju (ECO)}

Organizacija za ekonomsku suradnju (ECO) osnovana je nakon Hladnog rata. ECO nikada nije bila učinkovita regionalna organizacija. Zbog ključnog geo-strateškog položaja, Afganistan je imao ključni značaj u ECO-u zahvaljujući unutarnjim i vanjskim razlozima. Politička nestabilnost u Afganistanu također je bila faktor neučinkovitosti ECO-a. Članovi ECO-a imaju istu kulturnu, religijsku i povijesnu pozadinu. Jedan od ciljeva organizacije bio je uspostaviti željezničku i cestovnu vezu s regijom i Europom. Ova organizacija, nažalost nije uspjela primijeniti sporazum u njegovanju odnosa među državama članicama (Javaid i Khan, 2015). Organizacija za ekonomsku suradnju ili ECO je euroazijska politička i ekonomska međuvladina organizacija koju su 1984. godine u Teheranu osnovali čelnici Irana, Pakistana i Turske. ECO pruža platformu za raspravu o načinima poboljšanja razvoja i promicanju trgovine kao i mogućnosti ulaganja. ECO je ad hoc organizacija prema Povelji Ujedinjenih naroda. Cilj je uspostaviti jedinstveno tržište za robu i usluge. Upravljačke funkcije ECO-a su dislocirane, odnosno tajništvo ECO-a i odjel za kulturu nalaze se u Iranu, njegov ekonomski ured je u Turskoj, a njegov znanstveni ured nalazi se u Pakistanu. ECO je međuvladina regionalna organizacija koja obuhvaća zemlje iz Europe, Kavkaza i Središnje Azije, Bliskog istoka i Južne Azije s više od 460 milijuna stanovnika i preko 8 milijuna četvornih kilometara koji povezuju Rusiju s Perzijskim zaljevom i Kinom u Europu. Tijekom posljednja tri desetljeća, ECO države članice surađuju kako bi ubrzale tempo regionalnog razvoja kroz svoje zajedničke napore. Osim zajedničkih kulturnih i povijesnih afiniteta, uspjeli su iskoristiti postojeću infrastrukturu i poslovne kontakte kako bi prenijeli svoje znanje u realni sektor. U 2017. godini države članice na svojem 13. sastanku u Istanbulu odobrili su „ECO Vision 2025“, gdje se definiraju glavni smjernice ECO poslovanja. ECO Vision 2025" temelji se na načelima "Održivosti", "Integracija" i "Dobro upravljanje". područja:

Ova vizija se fokusira je na šest područja suradnje, odnosno prioritetna

1. Trgovina

2. Transport i povezivanje

3. Energija

Kao što naziv organizacije ECO podrazumijeva, najvažniji je sektor trgovine i ulaganja. Širenje u globalnoj i unutar regionalnoj trgovini mogu utjecati na poboljšanje ekonomije članica države. Svjetska trgovina ECO-a smanjila se za 3,4\% u 2016. (s 648 \$ milijardi u 2015. na 626 milijardi \$). Međuregionalna trgovina (trgovina među zemljama ECO) smanjila se na 7,6\% ukupne trgovine država članica, što je daleko ispod potencijala ECO-a. Ovo nije zabrinjavajuće u usporedbi s drugim regionalnim 
organizacijama. Unutar ECO-a, vodeći izvoznici su Turska, Kazahstan, Iran, Pakistan i Azerbajdžan. Ovih pet zemlje čine 94\% ukupnog izvoza ECO-a.

\section{Crnomorska ekonomska suradnja (BSEC)}

Crnomorska ekonomska suradnja (BSEC) sastoji se od 12 zemalja članica (Albanija, Armenija, Azerbejdžan, Bugarska, Gruzija, Grčka, Moldavija, Rumunjska, Rusija, Srbija i Crna Gora, Turska i Ukrajina), što daje ovom pokretu prednost po svojoj geostrateškoj poziciji. Regija BSEC nalazi se na raskrižju putova između Europe, Azije i Bliskog istoka i ima ukupno 330 milijuna stanovnika te je bogata naftom, prirodnim plinom i sirovinama.

Kao pokretač koncepta BSEC, Turska radi na poboljšanju svojih bilateralnih gospodarskih i trgovinskih veza sa svakom od zemalja članica, te također doprinosi razvoju multilateralnih struktura. Privatni sektor ima ključnu ulogu u poboljšanju odnosa, a turska vlada podržava poslovno okruženje kako bi im pružila konkurentsku prednost.

Ciljevi BSEC-a iz područja poljoprivrede i agroindustrije su:

- poboljšanje održive ruralne produktivnosti i povećanje međunarodne konkurentnosti država članica u hrani i poljoprivrednim proizvodima, posebice kroz: olakšavanje pristupa novim tehnologijama i know-howu, povećanje upravljačkih inovacija te usklađivanje i usvajanje standarda kvalitete za proizvode.

- promicanje razmjene informacija, iskustva i najbolje prakse među nadležnim tijelima, nacionalnim referentnim laboratorijima, agrarnim istraživačkim i obrazovnim institucijama i poduzećima iz privatnog sektora u područjima poljoprivrede, agroindustrije i sigurnosti hrane u državama članicama.

- promicanje djelotvornog i održivog korištenja zemljišnih resursa za poljoprivrednu proizvodnju u državama članicama BSEC-a.

\section{Svjetska trgovinska organizacija (WTO)}

Temeljni cilj WTO je postizanje održivog rasta i razvitka gospodarstava, opće dobrobiti, liberalnog trgovinskog okruženja, te doprinos postizanju bolje suradnje $u$ vođenju svjetske ekonomske politike. Turska je postala članica WTO-a 26. ožujka 1995. te je preuzela nova prava $\mathrm{i}$ ispunila svoje obveze kako u područjima obuhvaćenim GATT-ovim disciplinama, tako i u novim područjima kao što je Sporazum o trgovini uslugama, TRIPS i TRIMs. WTO svim svojim članovima daje tri posebne pogodnosti. Prvo, WTO dodjeljuje svakom članu status najpovlaštenije nacije, što znači da članice WTO-a moraju međusobno postupati jednako. Svima omogućava podjednaku povlaštenu trgovinsku korist. Drugo, članice WTO-a međusobno imaju manje trgovinske prepreke. To uključuje tarife, uvozne kvote i propise. Niže trgovinske prepreke omogućuju članicama veća tržišta za svoju robu. Veća tržišta vode do veće prodaje, više radnih mjesta i bržeg gospodarskog rasta. Treće, oko dvije trećine članica WTO-a su zemlje u razvoju. Njihovo članstvo im daje neposredan pristup razvijenim tržištima po nižoj tarifnoj stopi. To im daje vremena da sustignu sofisticirane korporacije i industrije. Oni ne moraju ukloniti uzajamne tarife na svojim tržištima, 
odnosno zemlje u razvoju ne moraju odmah otvoriti svoja tržišta te se na taj način mogu privremeno oduprijeti konkurenciji.

Cilj Turske za članstvo u GATT-u, a kasnije i u Svjetskoj trgovinskoj organizaciji bio je postati dio Zapada i integrirati se u globalnu ekonomiju, modernizirati njezino gospodarstvo i poboljšati svoje vanjskotrgovinske odnose. Iako je Turska jedan od osnivača drugih međunarodnih organizacija, inače je cijenjen član $u$ tzv. socijalnom klubu bogatih nacija (OECD), u WTO-u Turska ima status države u razvoju. Također je važno napomenuti da turski status kao zemlje kandidata za EU presudno utječe na njezine političke opcije u WTO-u (Pulat, 2013).

\section{EUROPSKA UNIJA I TURSKA}

Država koja je spremna za ulazak u EU trebala bi imati demokratski sustav vlasti. Prije ulaska država kandidat mora provesti pregovore u 35 odjeljaka koji pokrivaju sve sfere političkog, ekonomskog, javnog i pravnog života. Zemlja članica bit će prihvaćena u EU kada zaključi pregovore u svih 35 odjeljaka uz jednoglasno odobrenje svih država članica EU. Potrebna je određena razina zrelosti države kandidatkinje: usklađivanje nacionalnih zakona $\mathrm{s}$ zakonodavnom osnovom EU-a; pravilan ekonomski razvoj; i poštivanje osnovnih ljudskih vrijednosti i prava. Put Turske do Europske unije do sada je bio težak i kompliciran. Ova je zemlja željna suradnje s EU-om (i to čini) i spremna je udovoljiti europskim standardima i normama javnog života. Pregovori još uvijek traju; primjetan je napredak u ekonomiji Turske, iako Turska zaostaje u zaštiti ljudskih prava (Pukenis, 2014).

Kao kandidat za članstvo, Turska je stekla priznanje svojih europskih susjeda da pripada europskom klubu država - status koji su tražile turska i osmanska vlada gotovo 150 godina. Međutim, za razliku od drugih zemalja kandidata, pregovori o pristupanju ne mogu započeli sve dok Turska ne provede niz ekonomskih i političkih reformi (Yesilada, 2002.).

Među političkim razlozima treba spomenuti zabrinutost zbog ciparskog pitanja i turskog pravosudnog sustava, kao i evidenciju o ljudskim pravima u zemlji. Iako Turska mora provesti širok spektar reformi kako bi istinski postala zemlja liberalne demokracije, ona i dalje ostaje ilustrativni slučaj kontinuiranog provođenja demokratizacije iz koje susjedne zemlje mogu izvući važne pouke. Turska je uložila značajne napore u provođenju demokratskih reformi s ciljem ispunjavanja kopenhaških kriterija EU (Europska komisija MEMO 2013, 1). Vanjske prepreke članstvu u Turskoj povezane su s negativnim pristupom nekih europskih čelnika i strahom europskih građana. Ipak, nedavni tijek događaja daje valjanu nadu da će prije ili kasnije Turska dobiti člansku iskaznicu Europske unije (Pukenis, 2014). Međutim, 2015. godine Europska unije se suočila sa ogromnim migrantskim valom potaknutim ratom u Siriji. Tom prilikom EU je prihvatila gotovo milijun izbjeglica s Bliskog Istoka. 2016. godine s EU je s Tursko potpisala sporazum prema kojem bi Turska migrante zadržala izvan granica EU, a zauzvrat će dobiti značajnu političku pomoć te političku podršku. Međutim o drugim alternativnim mogućnostima odnosa između Turske i EU analiziraju 
autori Cianciara, i Szymanski (2019) koji se bave novim modelima međuovisnosti i politizaciji ovog odnosa.

\subsection{Sociološke i kulturološke prepreke}

Sociološka istraživanja otkrila su da i u turskom društvu raste broj euroskeptika. Europska unija izgubila je svoju privlačnost i mnogi Turci smatraju da pristupanje Turske EU više nije potrebno (Morelli 2013, Straus, 2013). To potvrđuje i istraživanje Akçay i Yilmaz (2012) provedeno 2006. godine koje je preciziralo da je 2/3 Turaka izgubilo vjeru u Europsku uniju i ne očekuju članstvo u Uniji. Velika većina turskih građana više ne podupire ulazak zemlje u EU (Akçay i Yilmaz 2012).

Turska vlada pokazala je čvrstu spremnost za nastavak reformskih napora i ubrzanje procesa demokratizacije zemlje (Europska komisija MEMO 2013, 1).

Kanbur i Bernat (2013) također su istražili tzv. europeizaciju Turske i pristupanje EU te tvrde da je Turska još prije 55 godina tražila pristupanje EU. Tijekom tog vremena, EU su se pridružile i druge zemlje, proširivši Europsku uniju sa 6 članova na 28. Projekcije ulaska Turske u EU su da u sljedećem desetljeću Turska još uvijek neće biti dio Unije. Autori su analizirali faktore zbog kojih su neki političari i ekonomisti zabrinuti potencijalnim članstvom Turske. Oni koji su protiv turskog članstva u EU ukazuju na nekoliko pitanja: tvrde da Turska nije dio Europe - geografski i kulturno. Osim toga, Turska ima veliki broj stanovnika (slika 2.), visoku stopu nezaposlenosti i migracije kao potencijalni problem za EU.

Slika 2. Kretanje turskog stanovništva (2009.-2018.)

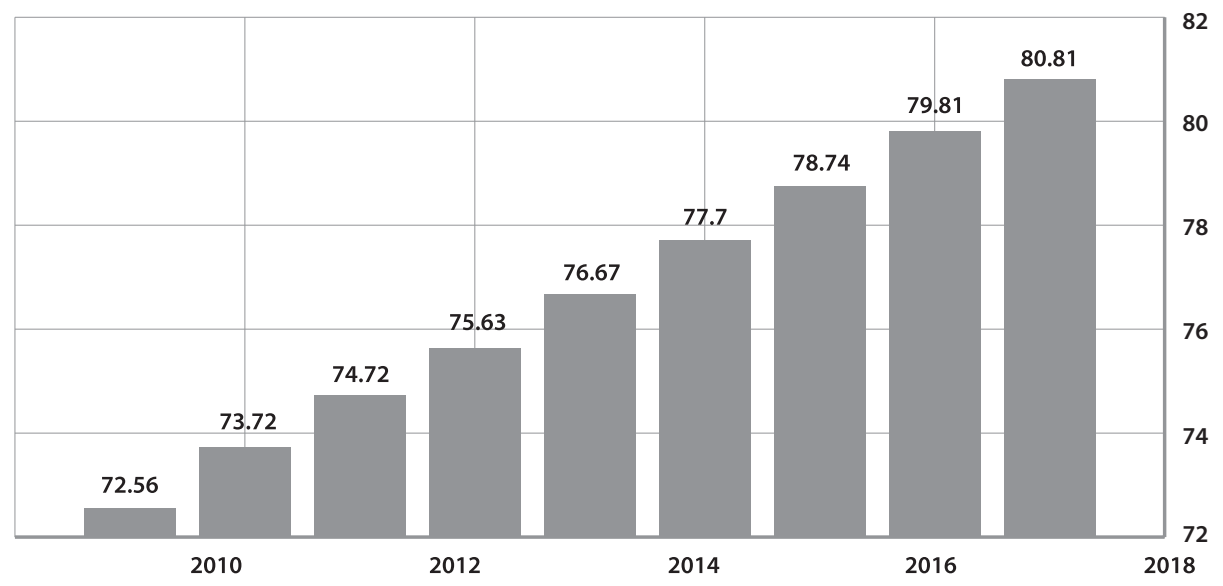

Izvor: https://statista.com/, 2019.

Turska danas ima nešto manje od 85 milijuna stanovnika, te ukupnu stopu fertiliteta (TFR; broj poroda po ženi) 2,26, malo iznad razine supstitucije koja iznosi 
2,1. Turska je danas zemlja niske razine nataliteta i mortaliteta. Ovaj fenomen koji je Turska postigla povezan je s nizom rizika, poput starenja stanovništva i opadanjem radno sposobnog stanovništva. Demografske (populacijske) politike koje se provode $u$ Turskoj mogu se podijeliti u tri glavne ere, na temelju ciljeva koje su trebale postići. Politika uvedena nedugo nakon utemeljenja Republike 1923., a trajala je do sredine 1960-ih. Ta politika favorizirala je visoku stopu rasta stanovništva (pronatalitetna politika) (Yavuz, 2006). Drugo razdoblje, koje počinje sredinom 1960-ih (Üner, 1984) i traje do prvog desetljeća 2000-ih, razdoblje je u kojem dominira cilj smanjenja stope rasta stanovništva (antinatalitetna). Od 2008. Turska je ponovno ušla u novu pronatalitetnu politiku - politika tri djeteta (Yüceşahin et al., 2016).

Analiza Gerhardsa i Hansa (2011) pokazuje da značajna većina građana odbacuje ideju pridruživanja Turske EU. Četiri čimbenika prilično dobro objašnjavaju ovakav stav europskih građana: ekonomska korist od turskog pristupa, kulturne razlike, politička ideologija i opći stav prema EU.

Taydas et al. (2017) također su istraživali razloge protivljenju ulaska Turske u EU. Oni tvrde da iako su strahovi od većeg doprinosa proračunu EU ulaskom Turske i procjene nacionalnih ekonomskih uvjeta najdosljedniji utilitaristički prediktori protivljenja građana ulasku potencijalnih članica EU, privrženost europskom identitetu i strahovi od gubitka kulturnog identiteta dva su najmoćnija prediktora javnog protivljenja. Suprotno očekivanjima, vjerska vezanost igra ograničenu ulogu u oblikovanju javne oporbe.

Često se tvrdi da su vjerske razlike ishodište javnog protivljenja turskom članstvu, dok su ekonomski razlozi oni koji idu u prilog turskom članstvu. Ipak, javno je mišljenje vrlo nestabilno. Rezultati de Vreesea et al. (2012) pokazuju da su ekonomski razlozi svima uvjerljivi, dok su kulturni (religijski) okviri snažno uvjetovani predispozicijama pojedinca o vjerskoj raznolikosti.

\subsection{Ekonomski čimbenici:}

Turska ima 17. najveći BDP u svijetu. Zemlja je članica osnivačica OECD-a i najvećih gospodarstava G-20. Poznato je da EU sa svojom carinskom unijom omogućava slobodniji protok robe i gospodarskih dobara kao i da značaj veličine tržišta zemalja pristupnica vrlo često ima presudnu ulogu prilikom proširenja EU na istok. Sporazumom o carinskoj uniji stupio je na snagu 31. prosinca 1995. godine. Opseg carinske unije $\mathrm{s}$ Turskom ograničen je na industrijske proizvode i prerađene poljoprivredne proizvode. Roba koja je u cijelosti dobivena ili proizvedena u carinskoj uniji ili koja je stavljena u slobodni promet u EU može prometovati bilo gdje na teritoriju carinske unije, sve dok su popraćeni dokazom o tom carinskom statusu. Carinska unija ne pokriva: poljoprivredne proizvode (kako je definirano Ugovorom iz Amsterdama) te proizvode od ugljena i čelika.

Tijekom vremena Carinska unija između Turske i EU pokazala je značajne nedostatke koje su se odrazili na trgovinu. Neki od nedostataka su:

1. Ograničen utjecaj: Turska nije uključenja u određivanje zajedničkih tarifa ili zajedničke trgovinske politike. 
2. Vanjska asimetrija: Sporazum o slobodnoj trgovini EU-a s trećim zemljama ne pokrivaju Tursku.

3. Transportni problemi: administrativni problemima o raznim deklaracijama, osiguranju i slično.

4. Trgovački udarci: antidampinški postupci.

5. Viza barijere: turski prijevoznici suočiti se s izazovom dobivanja potrebnih viza prije ulaska i prelazak EU.

U posljednja dva desetljeća carinska unija EU-Turska bila je okosnica okvira bilateralne trgovine. Za to vrijeme Turska je postala petom glavnom trgovinom s EU na globalnoj razini s vrijednošću bilateralne trgovine robom od 140 milijardi eura (2017.). Slično tome, EU je najvažniji trgovinski partner Turske, koja predstavlja 41\% Turske globalne trgovine. Jačanje ekonomske integracije ogleda se u pristupu tržištu $u$ poljoprivredi, poticanjem ulaganja u sektor usluga kroz bolje otvaranje i regulatorno djelovanje kao i modernizaciju carinske unije za daljnje proširenje bilateralnih trgovinskih odnosa na područja kao što su usluge, javna nabava i održivi razvoj. U 2018. godini Turska je bila peta najveća partnerica za izvoz robe iz EU i šesti po veličini partner za uvoz roba u EU.

Grafikon 3. 15 najvećih trgovinskih partnera Turske (izvoz)

UAE; 1,9

Egipat; 1,8

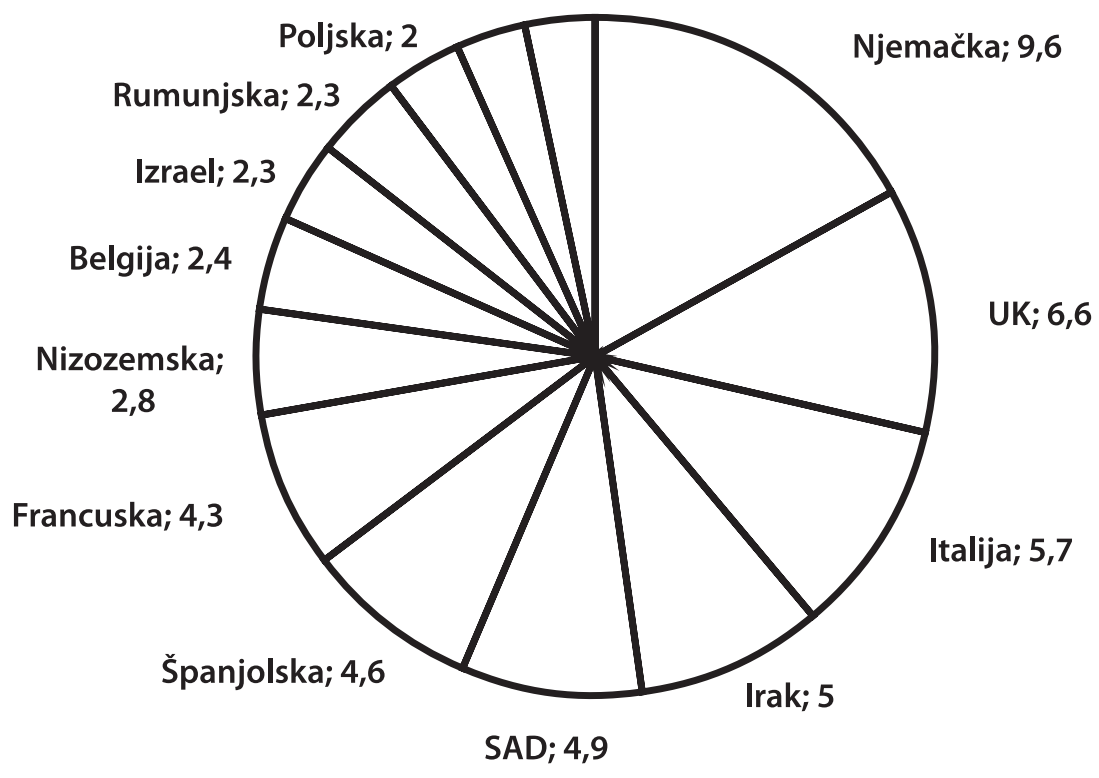

Izvor: http://worldstopexports.com/, 2019. 
U grafikonu 3 prikazano je 15 najznačajnijih trgovinskih partnera Turske, prema vrijednosti izvoza (\$) u 2018. godini. Isto tako možemo vidjeti kako su velik broj tih zemalja članice EU.

Njemačka je zemlja EU s kojom Turska ima najveće izvozno tržište. Njemačko-turski odnosi kulminirali su ojačanom suradnjom u gospodarskim, vojnim, kulturnim i društvenim odnosima. $\mathrm{S}$ velikom turskom dijasporom u Njemačkoj i mogućim pridruživanjem Turske EU veze su sve složenije. Obim bilateralne trgovine između Turske i Njemačke iznosio je 36,4 milijarde $\$$ u 2017. godini, što odgovara porastu od 3,1\% u odnosu na prethodnu godinu (izvoz 15,1 milijardi američkih \$, uvoz 21,3 milijarde \$) što je prikazano na slici 3. Glavne stavke izvoza Turske u Njemačku sastoje se od cestovnih vozila, dijelova i pribora za motorna vozila i dijelova za upotrebu s klipnim motorima, dok su glavne stavke uvoza Turske iz Njemačke cestovna vozila, lijekovi i dijelovi i pribor za motorna vozila. U Njemačkoj posluje oko 80 tisuća tursko-njemačkih tvrtki. Njihov godišnji promet iznosi oko 52 milijarde eura i zapošljava gotovo 500 tisuća ljudi u 50 različitih sektora. Ključni njemački poslovni subjekti u Turskoj su Deutsche Bank, Siemens, MAN i Volkswagen. Robert Bosch je najveća njemačka tvrtka u Turskoj, a zapošljava 16.500 radnika.

Slika 3. Grafički prikaz Turskog izvoza u Njemačku (2009.-2017.)

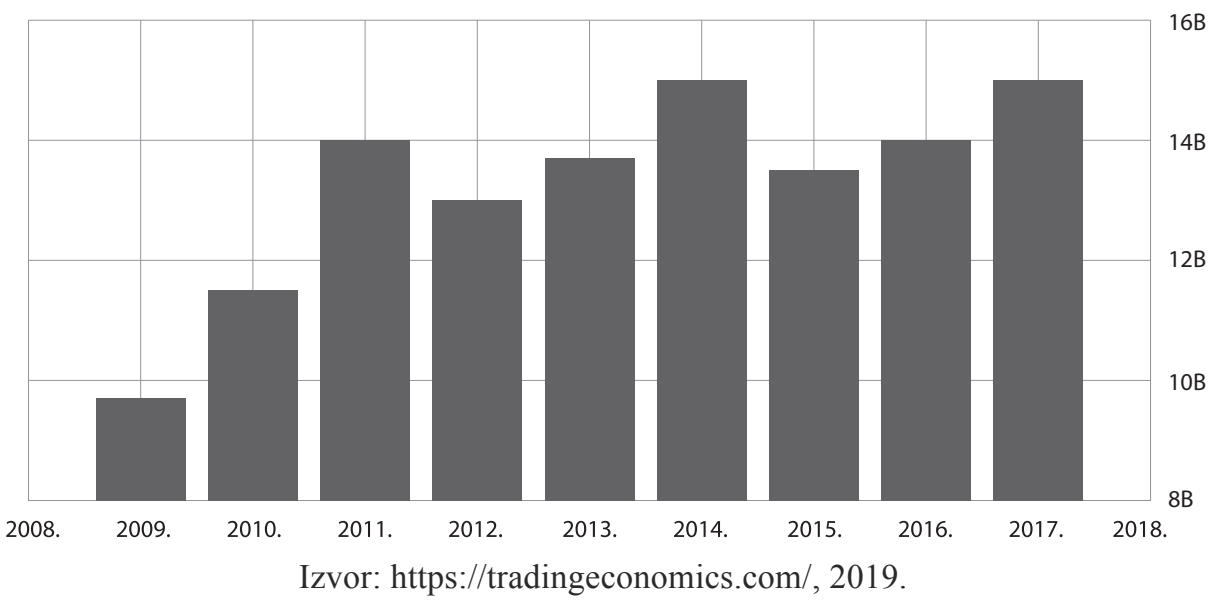

Godine 2017. najviše se u Njemačku iz Turske uvezlo vozila u vrijednosti od 2.92 milijuna \$, a na drugom mjestu su strojevi, nuklearni reaktori, kotlovi u vrijednosti od 2.31 milijuna \$. Što se tiče poljoprivrednih proizvoda najviše su se uvozili pripravci od voća, povrća i žitarica i orašastih plodova. Izvoz turske robe u Italiju iznosio je 9,46 milijardi \$ u 2018., dok je uvoz iz Turske iznosio 10,15 milijardi \$. Glavne stavke izvoza Turske u Italiju čine putnička motorna vozila, druga motorna vozila, svježe ili sušeno voće, dok su glavne stavke uvoza iz Turske dijelovi i pribor za motorna vozila, naftna ulja, jahte i druga plovila. Turska i Ujedinjeno Kraljevstvo imaju dobre bilateralne odnose. Godine 2017. Turska je u Ujedinjeno Kraljevstvo uvezla robu u 
vrijednosti od 9 milijardi 608 milijuna \$. Glavni turski izvoz u Ujedinjeno Kraljevstvo su zlato, gotovi tekstilni proizvodi, odjeća, električni i neelektrični strojevi, motorna vozila i dijelovi, proizvodi od željeza i čelika, izolirane žice, kabeli i drugi električni vodiči. Glavni uvoz iz Ujedinjenog Kraljevstva su dizelski i poludizelski motori, automobili, gvozdeni čelik i njihovi ingoti, medicinski i farmaceutski proizvodi.

\subsection{Politika i javno mišljenje}

Europska javnost podijeljena je oko pitanja ulaska Turske u EU. Najveći zagovornici ulaska Turske su Ujedinjeno Kraljevstvo, Italija, Španjolska, Švedska, Finska te Sociodemokratska stranka Njemačke. Mnogi europski političari misle da će tursko članstvo u EU uzrokovati nastanak ekonomskih i socijalnih problema i predstavljat će veliko opterećenje za proračun EU. Naročito desničarski politički krugovi protive se integracije Turske u Europsku uniju. Kršćansko-demokratske i konzervativne stranke u Njemačkoj, Francuskoj i Austriji često kritiziraju proces proširenja EU-a i zastupaju mišljenje da države kandidatkinje ne bi trebale biti primljene u Uniju. (Rios, 2012). Ujedinjeno Kraljevstvo kao lider zagovornica ističe kako Turska ima stratešku, energetsku i ekonomsku razvijenost, dok protivnici žele slabiju suradnju s Turskom. Brojne ankete javnog mnijenja pokazuju da protivnici pristupanja ne temelje svoje stavove na tehničkim i pravnim preprekama, već i na pretpostavljenim kulturološkim razlikama. U suvremenoj Europi, podrška nastavku europskih integracija određena je kako „tvrdim“ ekonomskim čimbenicima korisnosti, tako i „mekanim“ čimbenicima kao što su osjećaj identiteta i stavovi prema imigrantima. U analizi stavova europskih građana, većinskom protivljenju turskom članstvu najviše doprinose upravo „mekani“ čimbenici. Nužno je istaknuti kako je i potpora turskih građana EU u opadanju kao posljedica zaokreta domaće politike, prekomjernih zahtjeva o nužnosti prilagodbe zakonodavstva te dugotrajne neizvjesnosti koje obilježava cjelokupni proces.

Veliki migracijski val koji je počeo još 2015. godine, a traje i danas ponovo je stavio Tursku u središte geopolitičkog interesa Europske unije. Nakon prihvata gotovo milijun migranata u prvom valu 2015., EU se suočila sa značajnim problemima asimilacija izbjeglica, financijska i logistička pomoć te terorizam. Brojni teroristički napadi povezuju se s neorganiziranim prihvatom velikog broja izbjeglica. Nakon toga Europska unije je prestala biti otvorena za migrante. Slijedom ovih događaja, 2016. godine EU s Turskom potpisala sporazum prema kojem se Turska obvezuje zadržati migrante u kampovima, a zauzvrat će primiti značajnu financijsku pomoć. Zauzvrat Turska od EU traži političku podršku vezanu za rat u Siriji i rješavanje kurdskog pitanja.

\section{DISKUSIJA}

Usprkos nesumnjivom ekonomskom vanjskotrgovinskom značaju Turske u europskom i svjetskom konceptu te snažne međusobne ovisnosti Turske i EU, odnosi EU i Turske jako su nestabilni. Ovaj rad se bavi „tvrdim“ efektima ekonomske korisnosti te „mekim“ efektima kao što su javno i političko mišljenje. S jedne strane 
Turska ima 17. najveći BDP u svijetu, zemlja je članica osnivačica OECD-a i članica skupine G-20, a s druge strane „meki“ efekti, pogotovo u zadnje vrijeme diktiraju međusoban odnos.

Fluktuacijski odnos Turske i EU detaljno analizira Yilmaz (2019) koji njihove odnose dijeli na pojedina razdoblja:

- EU kao demokratski cilj (1999-2004): u tom razdoblju i EU i Turska imali su pozitivno mišljenje o ulasku Turske u EU;

- $\quad$ EU kao razočarenje (2005-2007): kada su Njemačka, Francuska i Austrija bile među članicama koje su bile protiv punopravnog članstva Turske kojoj su nudile tzv. „privilegirano partnerstvo“ umjesto punopravnog članstva. Osim toga, u ovom periodu važno pitanje je bilo zamrznuti odnos sa Ciprom i njegove reperkusije na Tursko članstvo u EU.

- $\quad$ EU kao nepouzdan entitet (2008-2012): u ovom periodu se nastavlja diskurs vodeće Stranke pravde i razvoja (AKP) prema EU i pristupanja Turske u EU. U tom periodu značajno je opala i javna turska podrška ulasku u EU

- $\quad$ EU kao neprijatelj 2013 - danas: ovaj period počeo je demonstracijama 2013. godine kada je Europski parlament kritizirao odgovor turske policije i vlasti prema demonstrantima. 2015. godine kreiran je Zajednički akcijski plan EU i Turske kao odgovor na migrantsku krizu. Iako se klima odnosa promijenila prema pozitivnim odnosima EZU i Turske, nakon sporazuma o migrantima ponovno je nastupila faza dubokog obostranog nepovjerenja.

Bez obzira na sve međusobne probleme, kao što su sociološke, kulturne i političke prepreke, EU i Turska su međusobno jako ovisne strane. S jedne strane Turska želi osigurati političku stabilnost i ekonomski rast, a EU treba pomoć Turske za rješavanje migrantske krize. Odnos EU i Turske više nije funkcionalan što dovodi do mišljenja da se zamrzne ili čak da se odustane od zahtjeva Turske za članstvo u EU. Gamawa (2019) ide korak dalje pa se bavi utjecajem Brexit-a na zahtjev Turske u EU te tvrdi da članstvo Turske ipak ne može biti u potpunosti isključeno bez obzira na posljedice kako za Tursku, tako i za EU. Saatcioglu (2020) to dokazuje da je „,izbjeglički dogovor“ iz ožujka 2016. produbio funkcionalnu suradnju usred materijalnih i normativnih ustupaka koje je EU dodijelila Ankari.

Izvjesno je da se novi model odnosa EU i Turske mora ponovno konceptualizirati uvažavajući evoluciju međusobnog odnosa koja je rezultat integracijskih i dezintegracijskih pritisaka. Cianciara (2019) tvrdi da praktično provođenje novog modela koje je ograničeno nizom izazova i uvjeta iz okruženja, te koji ovisi o sklonostima i interesima ključnih sudionika: institucija EU, zemlje članice i Turske.

\section{ZAKLJUČAK}

Turska je zemlja koja značajno dominira u europskom okruženju vanjskotrgovinskog poslovanja. Makroekonomski indikatori upućuju na pozitivan prirodni prirast, porast izvoza za 7,1\% (2018), rast BDP za 2,6\% (2018) te se svrstava 
na 17. mjesto prema veličini BDP u svijetu. Turska je 29. najveći izvoznik u svijetu i zauzima 21. mjesto na globalnoj listi najvećih uvoznika. Ova zemlja također je lider u proizvodnji pšenice, šećerne repe, mlijeka, peradi, pamuka, rajčica i drugog voća i povrća, te je najveći proizvođač u svijetu marelica i lješnjaka. Izvoz roba i usluga u Turskoj čine 24,9\% ukupnog BDP zemlje a najznačajniji joj je partner - Europska unija (41\%), odnosno Njemačka je najveće izvozno tržište Turske. Rezultati istraživanja pokazuju kako se Turska susreće s raznim izazovima kako bi postala članica EU. Iako se Turska prvi put prijavila za pristupanje EU prije 45 godina, ona je jedina zemlja kandidat, koja još nije započela pristupne pregovore. U radu su se istražili čimbenici odnosa Turske kroz demografske, sociološke, kulturološke, ekonomske i političke izazove koji pokazuju kako je integracija Turske u Europsku uniju određena kako „tvrdim “ ekonomskim čimbenicima korisnosti, tako i „,mekanim “ čimbenicima kao što su osjećaj identiteta, religije kao i stavovima prema imigrantima. Iako Turska pokazuje pozitivne ekonomske trendove u europskom kontekstu, „mekani“ čimbenici ipak predstavljaju osnovnu barijeru integracije. Veliki migracijski val koji je počeo još 2015. godine, a traje i danas ponovo je stavio Tursku u središte geopolitičkog interesa, ali i naglasio međusobnu ovisnost Turske i EU te potrebu konceptualizacije novog modela međusobnih odnosa.

\section{LITERATURA}

1. Abuselidze, G., Mamaladze, L. (2019). U.S-Turkey Crisis and Its Impact on the Economy of the Black Sea Region, ITESE-2019, Web of Conferences 135, 03077, str.1-17.

2. Akçay, B., Yilmaz, B. (2012). Turkey's Accession to the European Union: Political and Economic Challenges. Plymouth. Lexington Books.

3. Andrijanić I. (2001). Vanjska trgovina: Kako poslovati s inozemstvom. Mikrorad.

4. Baban, Lj., Marijanović, G. (1998). Međunarodna ekonomija. Mikrorad.

5. Bencarić, L. (2019). Izazovi vanjskotrgovinskog poslovanja Republike Turske u europskom kontekstu. Diplomski rad. Fakultet agrobiotehničkih znanosti Osijek, Osijek

6. Cianciara, A.K., Szymanski, A. (2019). Differentiated integration: towards a new model of European Union-Turkey relations? Jorunal Turksih Studies, Volume 21, Issue 2, str. 254-273.

7. De Vreese, C.H., Brug, W., Hobolt, S. (2012). Turkey in the EU?: How cultural and economic frames affect support for Turkish accession. Macmillan Publisher Ltd. 1472-4790. Comparative European Politics. Vol. 10, 2, str.218235.

8. Erduman, Y., Eren, O., Gül, S. (2019). The Evolution of Import Content of Production and Exports in Turkey: 2002-2017, Central Bank of the Republic of Turkey, Research and Monetary Policy Department, Working Paper No: 19/09: str. 1-24. 
9. European Commission MEMO (2013). Key findings of the 2013 progress report on Turkey. http://europa.eu/rapid/press-release MEMO-13-895 en.htm (pristupljeno 11.06.2019.)

10. Gamawa, Y. I. (2019). Turkey's EU Membership: Perception, Brexit, Implications and Possibilities. American International Journal of Humanities, Arts and Social Sciences, 1(1), str. 4-11.

11. Gerhards, J., Hans, S. (2011). Why not Turkey? Attitudes towards Turkish Membership in the EU among Citizens in 27 European Countries. Jounal of Common Market Studies, Vol. 49 (4): 741-766.

12. Javaid, F., Khan, M.A. (2015). The Role of Economic Cooperation Organization (ECO) in Central Asia: An analytical study. Research Jounal of Social Studies (WIFAQIYAN). Vol. 1 (2), str. 68-76.

13. Kanbur, M., Bernat, T. (2013). Europeanization in Turkey and accession process to the European Union. Journal of International Studies, 6(2), str.7993.

14. Matić, B. (2004). Međunarodno poslovanje. Sinergija.

15. Morelli, V. (2013). European Union Enlargement: A Status Report on Turkey's Accession Negotiations.

16. Pukenis, R. (2014). The enlargement of the European Union and the (non) membership of Turkey. European Scientific Journal, vol. 10, no. 22: str. 393413.

17. Pulat, M. (2013). The World Trade Organization and Turkey. http://turkishpolicy.com/images/stories/2013-03-economyreloaded/TPQ20033-pulat.pdf (pristupljeno 10.5.2020.)

18. Rios, J. A. (2012). The Turkish accession in the European Union and the Kurdish question. https://www.academia.edu/1761105/The accession_of Turkey_in the EU an d the Kurdish questio

19. Saatcioglu, B. (2020). The European Union's refugee crisis and rising functionalism in EU-Turkey relations. Turkish studies Journal. Vol. 21 (2). str. 169-187.

20. Straus, K. (2013). Coming it from the cold - why Turkey should join the European Union.

21. Taydas, Z., Cigdem Kentmen-Cin, C. (2017). Who Is Afraid of EU Enlargement? A Multilevel Comparative Analysis. Political Research Quaterly, Volume: 70 issue: 3; str. 604-617.

22. Üner, S. (1984). Türkiye Nüfusu: Boyutlar, Sorunlar, Yorumlar (Turkey’s Population: Dimensions, Problems, Commentaries), Ankara: Hacettepe University Institute of Population Studies Press.

23. Yavuz, S. (2006). Completing the Fertility Transition: Third Birth Deve lopments by Language Groups in Turkey. Demographic Research 15; str. 435460.

24. Yesilada, B,A. (2002). Turkey's Candidacy for EU Membership. Middle East Journal, Vol. 56, No. 1 (Winter, 2002), str. 94-111. 
25. Yilmaz, G. (2019). from Eu-phoria to Eu-phobia? changing turkish narratives in Eu-turkey relations. Baltic Journal of European Studies. Vol. 9 (1). str. 20 32.

26. Yüceşahin, M.M., Adali, T., Türkyılmaz, A.S. (2006). Population Policies in Turkey and Demographic Changes on a Social Map. Border Crossing, Volume: 6, No: 2, str. $240-266$.

27. http://www.worldstopexports.com/turkeys-top-10-exports/ (pristupljeno 18.03.2019)

28. http://datatopics.worldbank.org/world-development-indicators/ (pristupljeno 06.06.2019.)

29. https://www.fas.usda.gov/data/turkish-agricultural-exports-continue-surge (pristupljeno 18.03.2019.)

30. https://tradingeconomics.com/turkey/imports-by-country (pristupljeno 25.03.2019.)

31. https://www.statista.com/statistics/255454/-population-growth-in-turkey/, 2019. (pristupljeno 03.04.2019.)

32. http://www.fao.org/countryprofiles/index/en/?iso3=TUR (pristupljeno 04.04.2019.)

33. http://www.worldstopexports.com/turkeys-top-10-exports/, 2019. (pristupljeno 24.04.2019.)

34. https://tradingeconomics.com/turkey/exports/germany (pristupljeno 29.05.2019.) 


\title{
TURKEY IN EUROPEAN CONTEXT OF INTERNATIONAL TRADE
}

\author{
Tihana Sudarić, Lucija Bencarić \& Ružica Lončarić
}

\begin{abstract}
Summary
Foreign trade has great significance in the economy of each country through a multiplier effect reflected not only through economic components but also through socio-cultural development. The aim of the paper was to identify Turkey in the European context of international relations, that is, to highlight Turkey's comparative and competitive role in foreign trade. Factors of the relationship between the Republic of Turkey and the European Union are: demographic aspects, sociological and cultural differences, access to critique, economic aspects and political challanges. In the last two decades, the EU and Turkey customs union was the cornerstone of bilateral trade. At that time, Turkey became the world's fifth largest trade with the EU on a global scale worth EUR 140 billion in 2017. Similarly, the EU is Turkey's most important trading partner, representing $41 \%$ of Turkey's global trade. The research in this paper is based on the analysis of secondary data sources, and synthesis and descriptive methods have been applied in the interpretation of the obtained results and the formation of conclusions. The results of the study show that Turkey's integration into the European Union is determined by both "hard" economic utility factors and "soft" factors such as a sense of identity, religion or attitudes towards immigrants. Although Turkey shows positive economic trends in the European context, "soft" factors still represent the primary barrier to integration. The great migration crizis that began in 2015, and continues today, has again put Turkey at the center of geopolitical interest, but also emphasized the interdependence of Turkey and the EU and the conceptualization of a new model of mutual relations.

Key words: foreign trade, import, export, culturological differences the Republic of Turkey, European Union.
\end{abstract}

